\title{
Soil acidification increases metal extractability and bioavailability in old orchard soils of Northeast Jiaodong Peninsula in China
}

\author{
Lianzhen $\mathrm{Li}^{\mathrm{a}}$, Huifeng $\mathrm{Wu}^{\mathrm{a}, * *}$, Cornelis A.M. van Gestel ${ }^{\mathrm{b}, *}$, Willie J.G.M. Peijnenburg ${ }^{\mathrm{c}, \mathrm{d}}$, \\ Herbert E. Allen ${ }^{\mathrm{e}}$ \\ ${ }^{a}$ Key Laboratory of Coastal Zone Environmental Processes and Ecological Remediation, Yantai Institute of Coastal Zone Research (YIC), Chinese Academy of \\ Sciences (CAS), Shandong Provincial Key Laboratory of Coastal Zone Environmental Processes, YICCAS, Yantai, Shandong 264003, PR China \\ ${ }^{\mathrm{b}}$ Department of Ecological Science, Faculty of Earth and Life Sciences, VU University, De Boelelaan 1085, 1081 HV Amsterdam, The Netherlands \\ ${ }^{c}$ National Institute of Public Health and The Environment, Laboratory for Ecological Risk Assessment, P.O. Box 1, 3720 BA Bilthoven, The Netherlands \\ ${ }^{\mathrm{d}}$ Institute of Environmental Sciences (CML), Leiden University, Leiden, The Netherlands \\ e Department of Civil and Environmental Engineering, University of Delaware, Newark, DE 19716, USA
}

\section{A R T I C L E I N F O}

\section{Article history:}

Received 29 November 2013

Received in revised form

2 February 2014

Accepted 7 February 2014

\section{Keywords:}

Soil acidification

Orchard

Vineyard

Metal bioavailability

Earthworm

\begin{abstract}
A B S T R A C T
The bioavailability of $\mathrm{Cu}, \mathrm{Zn}, \mathrm{Pb}$ and $\mathrm{Cd}$ from field-aged orchard soils in a certified fruit plantation area of the Northeast Jiaodong Peninsula in China was assessed using bioassays with earthworms (Eisenia fetida) and chemical assays. Soil acidity increased with increasing fruit cultivation periods with a lowest $\mathrm{pH}$ of 4.34. Metals were enriched in topsoils after decades of horticultural cultivation, with highest concentrations of $\mathrm{Cu}\left(132 \mathrm{~kg}^{-1}\right)$ and $\mathrm{Zn}\left(168 \mathrm{mg} \mathrm{kg}{ }^{-1}\right)$ in old apple orchards and $\mathrm{Pb}\left(73 \mathrm{mg} \mathrm{kg}{ }^{-1}\right)$ and $\mathrm{Cd}$ $\left(0.57 \mathrm{mg} \mathrm{kg}^{-1}\right)$ in vineyard soil. Earthworm tissue concentrations of $\mathrm{Cu}$ and $\mathrm{Pb}$ significantly correlated with $0.01 \mathrm{M} \mathrm{CaCl}_{2}$-extractable soil concentrations $\left(R^{2}=0.70, p<0.001\right.$ for $\mathrm{Cu} ; R^{2}=0.58, p<0.01$ for $\mathrm{Pb}$ ). Because of the increased bioavailability, regular monitoring of soil conditions in old orchards and vineyards is recommended, and soil metal guidelines need reevaluation to afford appropriate environmental protection under acidifying conditions.
\end{abstract}

(c) 2014 Elsevier Ltd. All rights reserved.

\section{Introduction}

Horticultural soils may contain elevated metal concentrations as a result of the application of agrichemicals and soil amendments. Soil acidification may increase the bioavailability of these metals worsening its contamination condition. Soil $\mathrm{Cu}$ accumulation has been reported in the surface layer of European and Australian vineyard soils (Delusia et al., 1996; Chopin et al., 2008; Wightwick et al., 2008). A similar increase in Cu has occurred in citrus orchards and avocado orchard soils with an established history of copperbased fungicide use, with current concentrations ranging between 110 and $1500 \mathrm{mg} \mathrm{kg}^{-1} \mathrm{Cu}$ (Fan et al., 2011; Merrington et al., 2002). Several studies in other countries have shown that substantial quantities of $\mathrm{Pb}$ and As may accumulate in orchard topsoils as a result of repeated lead arsenate application (Pendergrass and Butcher, 2006; Udovic and McBride, 2012; Hood, 2006).

\footnotetext{
* Corresponding author.

** Corresponding author.

E-mail addresses: hfwu@yic.a.cn (H. Wu), kees.van.gestel@vu.nl (C.A.M. van Gestel).
}

The region of the Northeast of Jiaodong Peninsula in China, which can be considered part of the so called "fruit belt" of North Latitude 36 of the world, has a long tradition of intensive horticultural crop production. In this region, some old orchards and vineyards are being planted with other crops for animal and human consumption. Subsequent changes in land use can promote a potential problem of metal bioavailability and toxicity that is strongly influenced by soil properties. Acidification was severe in orchard soils of the Northeast of Jiaodong Peninsula according to a preliminary investigation in 2007-2009, which indicated that topsoil $\mathrm{pH}$ in $60.4 \%$ of the 268 investigated sites was less than 5.5 (with $27.2 \%$ less than 4.5 ). Nitrogen fertilization and irrigation are crucial for sustainable fruit production. Excessive application of $\mathrm{N}$ may, however, produce more acidity than actually necessary. Fruit trees also take up a large amount of cations from the soils each growing season (Tang et al., 2000). Over time, soils may become more acid due to the removal (loss) and leaching of exchangeable bases such as calcium and magnesium, which is especially pronounced in the coastal sandy textured soils with low nutrient-holding buffering capacity (i.e., the Northeast of Jiaodong Peninsula). Surface soil acidification and the effect on metal bioavailability have been investigated in laboratory and field studies (Allen, 2002; 


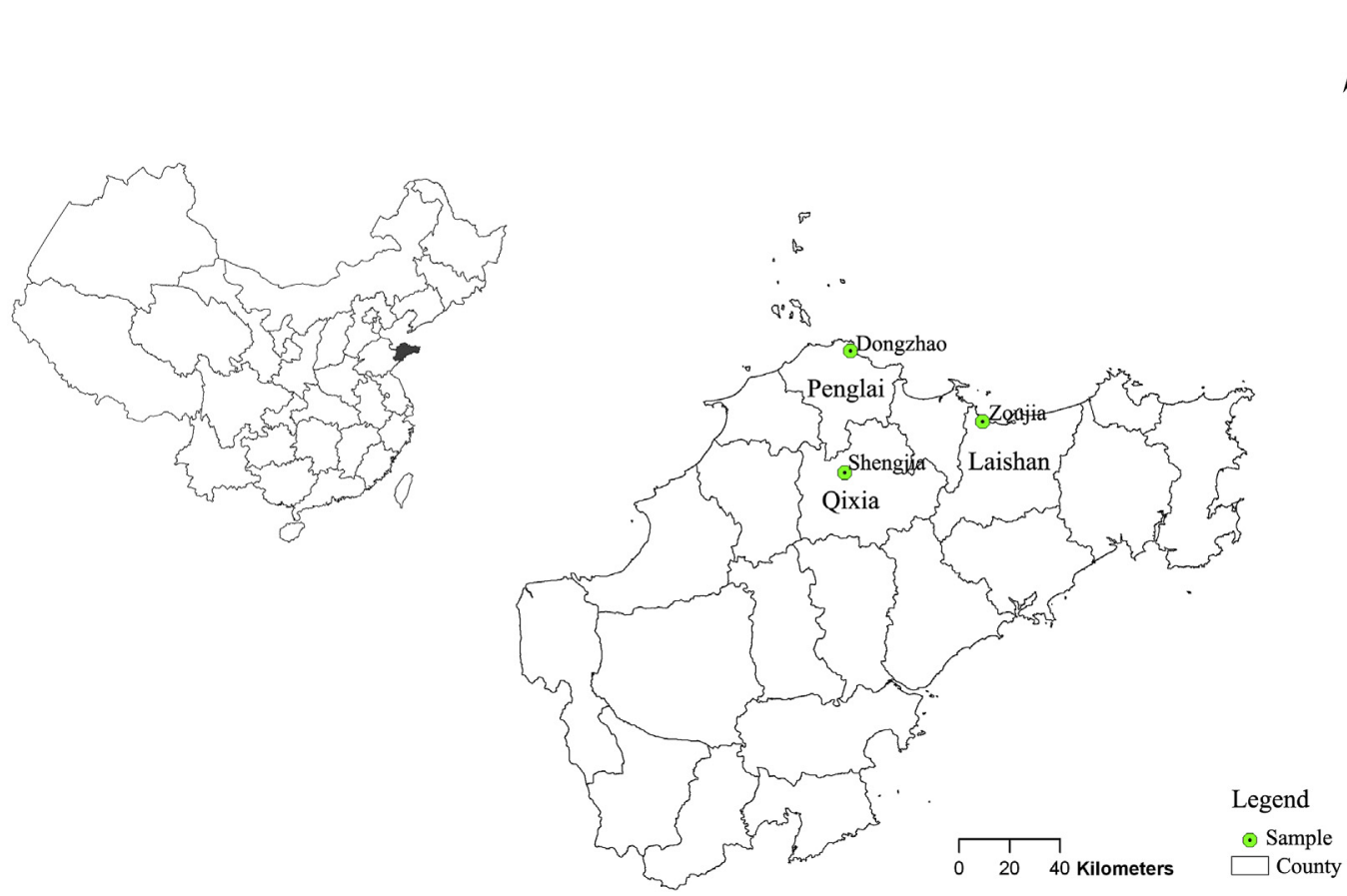

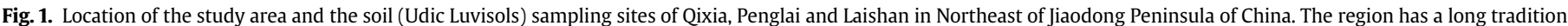
of intensive horticultural crop production.

Peijnenburg et al., 1999; Guo et al., 2011). However, there is little knowledge of subsoil acidity in the Northeast of Jiaodong Peninsula fruit-growing area, although topsoil acidification has become a major problem in soils of intensive Chinese agricultural systems (Guo et al., 2010). As the root system of most species of tree fruit are in the subsurface soil horizon, it is most vital to assess soil acidification in this layer and address its effects on metal bioavailability.

In general, there are two empirical approaches to assess availability of contaminants: chemical and biological testing. Of all chemical measures of bioavailability, chemical extraction techniques are commonly used as has been reviewed by Peijnenburg et al. (2007). Measuring body residues in soil organisms provides a better indication of metal bioavailability than using total metal concentrations in soil (Li et al., 2009; Conder and Lanno, 2003; Ma, 2005). Earthworms, because of their close contact with soil, are suitable organisms for assessing the bioavailability of contaminants in soil and the potential for these contaminants to enter terrestrial food chains (Spurgeon and Hopkin, 1999; Lock and Janssen, 2001; Vijver et al., 2006; van Gestel, 2012; OECD, 2004).

In this study, field and laboratory investigations were conducted to (1) study the accumulation and distribution of selected metals $(\mathrm{Cu}, \mathrm{Zn}, \mathrm{Pb}$ and $\mathrm{Cd})$ in the surface and subsurface soils of the fruit production region of Northeast of Jiaodong Peninsula in China; (2) determine whether intensive horticulture cultivation (including multiple management practices like tillage, fertilization, and irrigation) affects orchard and vineyard soil $\mathrm{pH}$ in the surface and subsurface layers; (3) evaluate the importance of soil solution $\mathrm{pH}$ on metal distribution and chemical speciation; and (4) estimate the availability of metals in soils using various chemical extractions as well as earthworm bioassays.

\section{Materials and methods}

2.1. Study area

The region of the Northeast of Jiaodong Peninsula has a marine climate, with humid air, ample sunlight and a high annual rainfall of $650-850 \mathrm{~mm}$, and is propitious to the growing of tree fruits, such as apple and grapevine. The soils in this area are brown soils (Udic Luvisols). The area has a long tradition of intensive horticultural crop production and has become a main region for apple production in China and one of the main regions for grape growing throughout the world.

\subsection{Soil sampling}

The soils were sampled in 2011 using a 0.10-m-diameter drill to collect samples from the vineyards in Penglai and two types of orchards, apple in Qixia and sweet cherry in Laishan. The studied orchards and vineyards were classified into three main categories based on their cultivation age, namely: Young, Adult and Old. Young orchards and vineyards were defined as those planted less than 10 years. Adult planted 10-30 years and Old planted more than 30 years ago. For each of the three cultivation age groups, triplicate soil samples from different locations were randomly collected at depths of $0-20 \mathrm{~cm}$ and $20-40 \mathrm{~cm}$, representing surface and subsurface horizons. To ensure representativeness in the sample from each triplicate, five soil sub-samples were randomly collected in the middle of rows located in the central portion of the stand. In this way, 15 soil sub-samples were obtained from each group of vineyards and orchards and subsequently mixed into a composite sample to obtain an accurate representation of the plot.

Samples were air-dried, ground and passed through a $2 \mathrm{~mm}$ Nylon sieve prior to analyses. Soil sample sites are shown in Fig. 1 in relation to the spatial distribution of vineyard and orchard sites.

\subsection{Physicochemical characterization of the soils}

The $\mathrm{pH}$ of soil samples was determined in triplicate at a 1:2.5 soil to water $(\mathrm{w} / \mathrm{v})$ ratio after shaking for one hour, using a glass electrode (Metrohm780 pH meter, Herisau, Switzerland). Total soil organic $\mathrm{C}$ was determined by combustion using a $\mathrm{C}$ / N analyzer (Vario MAX CN Macro Elemental Analyzer; Elementar Analysen System $\mathrm{GmbH}$, Germany). A laser analyzer Mastersizer 2000 (Malvern Instruments) with Hydro MU adapter was used to determine the particle-size distribution of soil samples.

\subsection{Soil metal analysis and extraction}

Soil samples were digested in a mixture of concentrated $\mathrm{HNO}_{3}-\mathrm{HF}-\mathrm{HClO}_{4}(\mathrm{v} / \mathrm{v} /$ $\mathrm{v}=5: 3: 2$; ultra pure grade, Sigma-Aldrich Shanghai Trading Co., Ltd, Shanghai, China), using a microwave digestion system (MAR-5, CEM Corporation, Matthews, NC, USA). Metal concentration was then determined by inductively coupled plasmamass spectrometry (ICP-MS; Agilent 7500i, Agilent Technologies Co. Ltd, USA). A certified reference soil (GBW07306, Polluted soil, State Bureau of Technical Supervision, People's Republic of China) was included as a means of quality control of the analysis. For all metals $(\mathrm{Cd}, \mathrm{Cu}, \mathrm{Pb}$, and $\mathrm{Zn})$ analyzed, measured concentrations were within $10 \%$ of the reported certified concentrations. 
Labile metal concentrations in the soils were estimated by two extraction methods: (a) $0.01 \mathrm{M} \mathrm{CaCl}_{2}$ (1:10 ratio of soil/0.01 $\mathrm{M} \mathrm{CaCl}_{2}$ ), 60 min equilibration time, yielding water extractable and readily exchangeable metals; (b) DTPA (diethylene triamine pentaacetic acid, 1:10 ratio of soil/DTPA solution), 60 min reaction time, extracting metals from the labile pools in soils. After extraction, the soil suspensions were centrifuged at $7500 \mathrm{~g}$ for $30 \mathrm{~min}$, and the supernatant was passed through a $0.45 \mu \mathrm{m}$ membrane filter.

To get insight into the availability of metals in the soils, soil metal was fractionated into five different fractions following the modified procedure of Amacher (1996). Soil samples $(2.0 \mathrm{~g})$ were sequentially extracted with $20 \mathrm{~mL}$ of $0.5 \mathrm{M}$ $\mathrm{Mg}\left(\mathrm{NO}_{3}\right)_{2}, 20 \mathrm{~mL}$ of $1 \mathrm{M} \mathrm{NaOAc}+\mathrm{HOAc}$ at $\mathrm{pH} 5,20 \mathrm{~mL}$ of $0.175 \mathrm{M}$ $\left(\mathrm{NH}_{4}\right)_{2} \mathrm{C}_{2} \mathrm{O}_{4}+0.1 \mathrm{M} \mathrm{H}_{2} \mathrm{C}_{2} \mathrm{O}_{4}$, and $20 \mathrm{~mL}$ of $0.8 \mathrm{M} \mathrm{NH}_{4} \mathrm{OAc}+0.0075 \mathrm{M} \mathrm{HNO}_{3}$ at pH 3 for the water-extractable and exchangeable (EXC), acid dissolved and carbonate bound (Carb), iron manganese oxide bound (FMO), and organic matter bound (OM) fractions, respectively. All metal analyses were performed using ICP-MS. The detection limits for $\mathrm{Cd}, \mathrm{Pb}, \mathrm{Cu}$ and $\mathrm{Zn}$ were $1,2,6$, and $12 \mathrm{mg} \mathrm{kg}^{-1}$, respectively.

\subsection{Soil solution extraction and measurements of ASV-labile metal}

Soil solutions were prepared by adding $10 \mathrm{ml}$ of $0.01 \mathrm{M} \mathrm{KNO}_{3}$ solution (ultra pure grade) to $10 \mathrm{~g}$ (dry weight) of soil in $50-\mathrm{ml}$ polyethylene centrifuge tubes. The supernatants (soil solutions) were separated by shaking the tubes overnight, centrifugation at $10,000 \mathrm{~g}$ for $10 \mathrm{~min}$ and filtering through $0.45-\mu \mathrm{m}$ cellulosic membranes. Soil-water partition coefficients $K_{p}\left(\mathrm{~L} \mathrm{~kg}^{-1}\right)$ were derived by dividing the total soil metal concentration ( $\mathrm{mg} \mathrm{kg}^{-1}$, dry weight) by the metal concentration $\left(\mathrm{mg} \mathrm{L}^{-1}\right.$ ) extracted with $0.010 \mathrm{M} \mathrm{KNO}_{3}$.

Labile concentrations of metals were determined by differential pulse anodic stripping voltammetry (DPASV) using a Metrohm 797 VA Computrace with 813 autosampler $\left(E_{d}=0.02 \mathrm{~V}\right.$ vs $\mathrm{Ag} / \mathrm{AgCl}$ (sat. $\left.\mathrm{KCl}\right), t_{d}=120 \mathrm{~s}, \nu=15 \mathrm{mV} \mathrm{s}^{-1}$ ). Details of the DPASV measurements can be found in (Sauvé et al., 2000; Stephan et al., 2008; Martinez-Villegas and Martinez, 2008). Theoretically, Cu, Cd and $\mathrm{Zn}$ can be determined simultaneously by DPASV, but sometimes $\mathrm{Zn}-\mathrm{Cu}$ intermetallic compounds may be formed inside the mercury drop if $\mathrm{Zn}$ and $\mathrm{Cu}$ are co-deposited. So we only measured $\mathrm{Pb}$ and $\mathrm{Cd}$ together in this study.

\subsection{Bioassays and metal analysis in the earthworm Eisenia fetida}

The earthworms E. fetida were purchased from a commercial source, cultured in cattle manure at a constant temperature of $20^{\circ} \mathrm{C}$, with moisture content of the culture substrate between $63 \%$ and $68 \%$.

Sexually mature E. fetida (i.e., having a fully developed clitellum), weighing $482 \pm 86$ mg wet wt (mean \pm SD; $n=86$ ), were selected from cultures, individually rinsed with deionized water. Prior to the test, each site soil was moistened to approximately $60 \%$ of the Water Holding Capacity (WHC). Soils (500 g, dry weight equivalent) were allocated in $1000-\mathrm{mL}$ test vessels. Worms were subsequently weighed to the nearest milligram and randomly distributed to the test vessels, with four worms per vessel. Tests were carried out in a climate room with constant temperature $\left(20 \pm 2{ }^{\circ} \mathrm{C}\right.$ ). The room was constantly illuminated (400-800 lux) to ensure that the worms remained in contact with the soil added to each vessel. Every two days, the moisture content was checked by reweighing the samples and deionized water was added if necessary to supplement water loss. Worms were not fed during the exposure. All exposures were performed in triplicate. After $28 \mathrm{~d}$, the earthworms were recollected from each container by hand sorting, rinsed in deionized water and depurated for $48 \mathrm{~h}$ on moist filter paper. After depuration, the earthworms were thoroughly rinsed in ultra pure deionized water, the fresh body weight was measured, the earthworms were frozen at $-20{ }^{\circ} \mathrm{C}$, freeze dried, and ground to a fine powder.

The earthworms were digested in $5.0 \mathrm{ml}$ concentrated $\mathrm{HNO}_{3}$ for $2 \mathrm{~h}$ at $120{ }^{\circ} \mathrm{C}$. Three $1.0 \mathrm{ml}$ portions of $\mathrm{H}_{2} \mathrm{O}_{2}$ were added to prevent over boiling, and the temperature was increased and kept at $150{ }^{\circ} \mathrm{C}$ for $1 \mathrm{~h}$. The solution was transferred to a 50-ml flask, and metal concentration was determined by ICP-MS. GBW08571 (Marine muscle tissue, State Bureau of Technical Supervision, People's Republic of China) was employed as a certified reference material for earthworm analyses. Measured concentrations were within $7 \%$ of the reported certified concentrations.

\subsection{Statistical analyses}

To facilitate comparison, earthworm metal concentrations were presented as the average values of three replicates. The differences between the soil metal concentrations were evaluated on the basis of one-way ANOVA for each depth level. Before testing, data were checked for normal distribution and homogeneity of variances with the Shapiro-Wilk test. The soil-water partition coefficients $K_{p}$ and the available metal concentrations, expressed as a percentage of the total metal concentrations (PTM), were analyzed by multiple linear regressions to evaluate the effects of soil properties on metal partitioning and availability. Stepwise selection with a significance level of 0.05 was used to obtain the model parameters. All data used for regression analysis were log-transformed in order to normalize their distribution. All the mentioned analysis was performed using the SPSS statistical software package, version 6.1 .

\section{Results}

\subsection{General characterization of soils}

Results for soil $\mathrm{pH}$, organic carbon content, and texture analyses are shown in Table 1 . The texture was similar in the surface and subsurface layer. The sand $(0.05-2 \mathrm{~mm})$ and silt fraction $(0.002-$ $0.05 \mathrm{~mm}$ ) predominated. Overall, the studied soils ranged from sand to silt loam, with clay content $<10 \%$ (Table 1 ). The carbon content of the studied soils ranged from 0.40 to $1.27 \%$ and was significantly higher in the surface soil layer $(0.89 \%$ on average) than in the subsurface ( $0.54 \%$ ) soils. Generally, the adult and old vineyard and orchard soils contained more organic carbon than the young ones (Table 1).

All soil samples showed significant acidification at both layers except for the young sweet cherry orchard and vineyard soils (Table 1 ), which had been cropped with fruit for several years only and on which small quantities of fertilizer and pesticides had been used in the past. Soil pH showed greater acidification in the adult and old vineyard (pH decreased by 2.8 and 3.1 units for surface and subsurface soil, respectively compared to young soils) and sweet cherry orchard ( $\mathrm{pH}$ decreased by 3.0 and 3.3 units) than in the apple orchards ( $\mathrm{pH}$ decreased by 1.6-3.0 units) (Table 1 ). However, there were no significant differences in $\mathrm{pH}$ between the two soil layers for the young age group, while significant subsoil acidification was seen for the adult and old soils (ANOVA, $p<0.05$, Table 1 ).

\subsection{Total metal accumulation in soils}

Fig. 2 shows the concentrations of metals accumulated in the soils at different sampling depths. The studied orchard and vineyard topsoils were enriched with metals, and the older the orchard and vineyard were the higher the metal enrichment in the soils. Metal concentrations in the subsurface layer were lower than those in the surface layer, although the subsoil showed a clear tendency of $\mathrm{Pb}$ and $\mathrm{Cd}$ accumulation in old orchards and vineyards. In addition to cropping history and soil depth, fruit variety may affect metal accumulation in the soil. A two-way ANOVA analysis for metals concentrations in topsoils revealed significant difference among orchard types ( $p<0.001$ for $\mathrm{Cu}, \mathrm{Zn}, \mathrm{Pb}$ and $\mathrm{Cd}$ ) and cropping history ( $p<0.001$ for $\mathrm{Cu}, \mathrm{Zn}, \mathrm{Pb}$ and $\mathrm{Cd})$.

(i) Total $\mathrm{Cu}$ concentrations in the topsoils of apple orchards in Qixia ranged from 63.6 to $132 \mathrm{mg} \mathrm{kg}^{-1}$ (Fig. 2). The lowest total $\mathrm{Cu}$ concentration was measured in the soil from the young (5 years old) apple orchard, the highest in the old apple orchard (35 years old; Fig. 2). The Cu concentration in the subsurface soil layer showed a low but consistent increase from 38.5 to $44.8 \mathrm{mg} \mathrm{kg}^{-1}$, after 30 years plantation (Fig. 2). Zinc levels in apple orchards soils slightly increased from 127 to $168 \mathrm{mg} \mathrm{kg}^{-1}$. Pb and Cd concentrations were elevated in both the surface and subsurface soils for the apple orchard in Qixia. The concentrations of $\mathrm{Cd}$ and $\mathrm{Pb}$ in surface soils in Qixia orchards were $0.27-0.41$ and 32.1$46.9 \mathrm{mg} \mathrm{kg}^{-1}$, respectively, and $0.19-0.26$ and $24.9-$ $33.9 \mathrm{mg} \mathrm{kg}^{-1}$, respectively, in subsurface soils (Fig. 2).

(ii) $\mathrm{Cu}$ and $\mathrm{Zn}$ concentrations increased with crop age in the surface layer of vineyard soils but were significantly lower than in the apple orchard in Qixia (ANOVA, $p<0.01$, Fig. 2). The vineyard soil had slightly higher $\mathrm{Pb}$ and $\mathrm{Cd}$ concentrations than all the other orchard soils. The total soil Pb concentrations ranged from 28.5 to $79.8 \mathrm{mg} \mathrm{kg}^{-1}$ in surface layers with an average of $53.1 \mathrm{mg} \mathrm{kg}^{-1}$ (Fig. 2). The total $\mathrm{Pb}$ concentration of surface layers was significantly higher than that of subsurface layers (ANOVA, $p<0.01$ ). 
Table 1

Sampling location, age and physicochemical characteristics of orchard and vineyard soils from Northeast of Jiaodong Peninsula, China.

\begin{tabular}{|c|c|c|c|c|c|c|c|c|c|c|}
\hline Site $^{\mathrm{a}}$ & Latitude & Longitude & Type & Group $^{b}$ & Layer $^{\mathrm{c}}$ & $\mathrm{pH}_{\mathrm{H}_{2} \mathrm{O}}(1: 2.5)$ & $\operatorname{SOC}^{\mathrm{d}}(\%)$ & Clay (\%)\% & Silt (\%) & Sand (\%) \\
\hline \multirow[t]{6}{*}{ Q } & $37^{\circ} 46^{\prime} 40.33^{\prime \prime}$ & $120^{\circ} 55^{\prime} 25.58^{\prime \prime}$ & Apple orchard & $\mathrm{Y}$ & Surface & $7.34 \pm 0.06$ & $0.76 \pm 0.10$ & $6.1 \pm 0.5$ & $54.4 \pm 5.0$ & $39.5 \pm 4.3$ \\
\hline & & & & & Subsurface & $7.81 \pm 0.03$ & $0.52 \pm 0.12$ & $5.7 \pm 0.6$ & $51.1 \pm 3.5$ & $43.2 \pm 5.4$ \\
\hline & & & & A & Surface & $5.21 \pm 0.03$ & $0.83 \pm 0.08$ & $5.7 \pm 0.8$ & $53.3 \pm 4.7$ & $41.0 \pm 3.9$ \\
\hline & & & & & Subsurface & $4.95 \pm 0.02$ & $0.48 \pm 0.18$ & $6.1 \pm 0.6$ & $51.3 \pm 6.3$ & $42.6 \pm 7.1$ \\
\hline & & & & $\mathrm{O}$ & Surface & $5.78 \pm 0.07$ & $1.27 \pm 0.13$ & $4.5 \pm 0.3$ & $48.0 \pm 5.5$ & $47.5 \pm 4.7$ \\
\hline & & & & & Subsurface & $4.83 \pm 0.02$ & $0.72 \pm 0.15$ & $5.2 \pm 0.4$ & $46.2 \pm 6.2$ & $48.6 \pm 5.3$ \\
\hline \multirow[t]{6}{*}{$\mathrm{P}$} & $37^{\circ} 21^{\prime} 17.58^{\prime \prime}$ & $120^{\circ} 47^{\prime} 26.58^{\prime \prime}$ & Vineyard & $\mathrm{Y}$ & Surface & $7.43 \pm 0.10$ & $0.65 \pm 0.12$ & $5.7 \pm 0.5$ & $60.0 \pm 5.9$ & $34.3 \pm 3.4$ \\
\hline & & & & & Subsurface & $7.50 \pm 0.10$ & $0.40 \pm 0.03$ & $6.5 \pm 0.7$ & $66.8 \pm 7.8$ & $26.7 \pm 3.7$ \\
\hline & & & & A & Surface & $5.22 \pm 0.08$ & $1.06 \pm 0.15$ & $6.2 \pm 0.8$ & $58.1 \pm 5.4$ & $35.7 \pm 4.0$ \\
\hline & & & & & Subsurface & $4.51 \pm 0.04$ & $0.47 \pm 0.02$ & $6.4 \pm 0.3$ & $68.9 \pm 9.3$ & $24.7 \pm 3.3$ \\
\hline & & & & $\mathrm{O}$ & Surface & $4.65 \pm 0.08$ & $0.72 \pm 0.11$ & $6.4 \pm 0.6$ & $53.7 \pm 3.2$ & $39.9 \pm 2.4$ \\
\hline & & & & & Subsurface & $4.41 \pm 0.08$ & $0.47 \pm 0.02$ & $7.0 \pm 0.5$ & $64.2 \pm 7.1$ & $28.8 \pm 2.5$ \\
\hline \multirow[t]{6}{*}{$\mathrm{L}$} & $37^{\circ} 25^{\prime} 46.01^{\prime \prime}$ & $121^{\circ} 47^{\prime} 06.67^{\prime \prime}$ & Sweet cherry orchard & $\mathrm{Y}$ & Surface & $7.61 \pm 0.07$ & $0.84 \pm 0.12$ & $5.6 \pm 0.8$ & $61.4 \pm 6.3$ & $33.0 \pm 1.7$ \\
\hline & & & & & Subsurface & $7.66 \pm 0.03$ & $0.42 \pm 0.05$ & $6.9 \pm 0.5$ & $62.0 \pm 5.1$ & $30.7 \pm 2.7$ \\
\hline & & & & A & Surface & $6.26 \pm 0.13$ & $0.85 \pm 0.13$ & $4.4 \pm 0.5$ & $50.5 \pm 3.2$ & $45.1 \pm 3.8$ \\
\hline & & & & & Subsurface & $4.77 \pm 0.12$ & $0.66 \pm 0.15$ & $5.5 \pm 0.2$ & $59.25 \pm 4.9$ & $35.3 \pm 3.1$ \\
\hline & & & & 0 & Surface & $4.67 \pm 0.04$ & $0.88 \pm 0.05$ & $5.7 \pm 0.9$ & $60.9 \pm 4.2$ & $33.4 \pm 7.6$ \\
\hline & & & & & Subsurface & $4.34 \pm 0.02$ & $0.40 \pm 0.03$ & $6.1 \pm 1.2$ & $63.5 \pm 9.2$ & $30.4 \pm 4.0$ \\
\hline
\end{tabular}

Data shown are mean values including standard deviation obtained from three replicates.

${ }^{a}$ Q: Qixia L: Laishan P: Penglai.

b Orchards and vineyard type: Young (Y, with age $<10$ years), Adult (A, with age 10-30 years), Old (O, with age $>30$ years).

c Surface: $0-20 \mathrm{~cm}$ subsurface: $20-40 \mathrm{~cm}$.

d Soil organic carbon content.

(iii) Concentrations of $\mathrm{Cu}$ and $\mathrm{Zn}$ in the surface soils of sweet cherry orchards were elevated with increasing age of the orchards (Fig. 2). Pb and Cd levels were only slightly increased in surface soils of the old sweet cherry orchard.
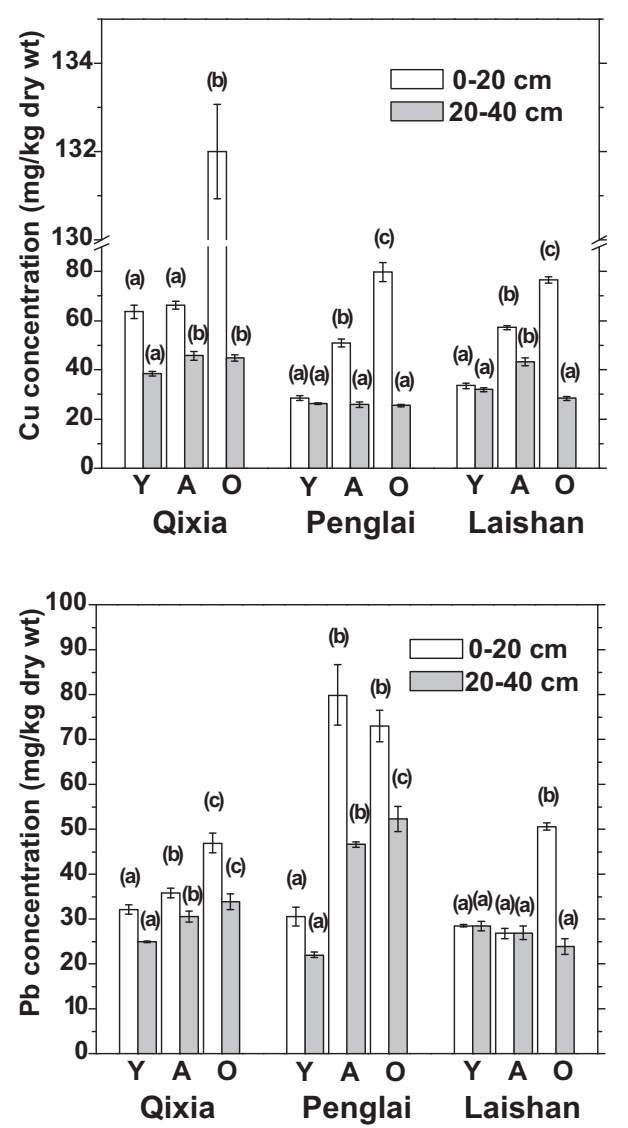

\subsection{Available metal concentrations in the soils}

$\mathrm{CaCl}_{2}$ extractable metal concentrations in the different soils are shown in Table 2. To avoid the effect of different total metal
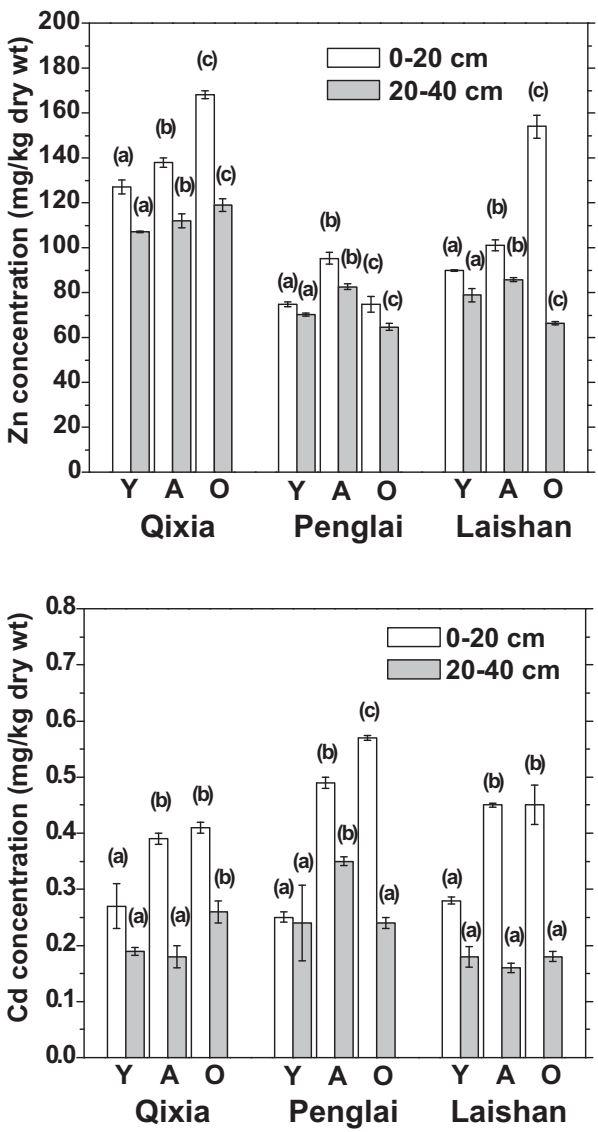

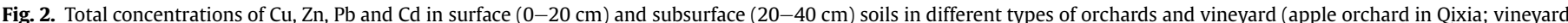

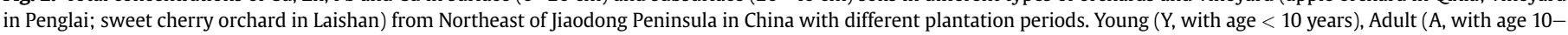
30 years), Old ( 0 , with age $>30$ years). 
Table 2

The $0.01 \mathrm{M} \mathrm{CaCl}_{2}$ extractable concentrations of $\mathrm{Cu}, \mathrm{Zn}, \mathrm{Pb}$ and $\mathrm{Cd}$ (mean $\pm \mathrm{SD}, n=3$ ) in the orchard and vineyard soils from Northeast of Jiaodong Peninsula in China.

\begin{tabular}{|c|c|c|c|c|c|c|c|}
\hline \multirow[t]{2}{*}{ Site $^{\mathrm{a}}$} & \multirow[t]{2}{*}{ Type } & \multirow[t]{2}{*}{ Group $^{b}$} & \multirow[t]{2}{*}{ Layer $^{c}$} & \multicolumn{4}{|c|}{$\mathrm{CaCl}_{2}$ extractable metal concentration ( $\mathrm{mg} \mathrm{kg}^{-1}$ dry soil) } \\
\hline & & & & $\mathrm{Cu}$ & $\mathrm{Zn}$ & $\mathrm{Pb}$ & $\mathrm{Cd}$ \\
\hline \multirow[t]{6}{*}{ Q } & \multirow[t]{6}{*}{ Apple orchard } & \multirow[t]{2}{*}{$\mathrm{Y}$} & Surface & $0.20 \pm 0.005$ & $0.87 \pm 0.02$ & $0.011 \pm 0.002$ & $0.0031 \pm 0.0004$ \\
\hline & & & Subsurface & $0.028 \pm 0.003$ & $0.289 \pm 0.05$ & $0.004 \pm 0.0006$ & $0.0043 \pm 0.0001$ \\
\hline & & \multirow[t]{2}{*}{ A } & Surface & $0.237 \pm 0.05$ & $0.098 \pm 0.02$ & $0.009 \pm 0.002$ & $0.009 \pm 0$ \\
\hline & & & Subsurface & $0.077 \pm 0.0003$ & $0.548 \pm 0.03$ & $0.005 \pm 0.0003$ & $0.012 \pm 0.0007$ \\
\hline & & \multirow[t]{2}{*}{0} & Surface & $0.319 \pm 0.09$ & $0.137 \pm 0.03$ & $0.007 \pm 0.001$ & $0.014 \pm 0.0001$ \\
\hline & & & Subsurface & $0.103 \pm 0.01$ & $1.03 \pm 0.09$ & $0.007 \pm 0.002$ & $0.010 \pm 0.0003$ \\
\hline \multirow[t]{6}{*}{$\mathrm{P}$} & \multirow[t]{6}{*}{ Vineyard } & \multirow[t]{2}{*}{$\mathrm{Y}$} & Surface & $0.030 \pm 0.017$ & $0.163 \pm 0.03$ & $0.005 \pm 0.001$ & $0.003 \pm 0.0003$ \\
\hline & & & Subsurface & $0.006 \pm 0.0011$ & $0.115 \pm 0.012$ & $0.002 \pm 0.00029$ & $0.0004 \pm 0.0002$ \\
\hline & & \multirow[t]{2}{*}{ A } & Surface & $0.132 \pm 0.019$ & $0.746 \pm 0.047$ & $0.0153 \pm 0.003$ & $0.019 \pm 0.00005$ \\
\hline & & & Subsurface & $0.040 \pm 0.02$ & $0.280 \pm 0.051$ & $0.011 \pm 0.001$ & $0.016 \pm 0.001$ \\
\hline & & \multirow[t]{2}{*}{$\mathrm{O}$} & Surface & $0.772 \pm 0.133$ & $0.896 \pm 0.019$ & $0.039 \pm 0.00399$ & $0.013 \pm 0.00024$ \\
\hline & & & Subsurface & $0.050 \pm 0.002$ & $0.330 \pm 0.08$ & $0.026 \pm 0.0033$ & $0.011 \pm 0.00049$ \\
\hline \multirow[t]{6}{*}{$\mathrm{L}$} & \multirow[t]{6}{*}{ Sweet cherry orchard } & \multirow[t]{2}{*}{$\mathrm{Y}$} & Surface & $0.022 \pm 0.001$ & $0.040 \pm 0.004$ & $0.0027 \pm 0.0002$ & $0.0030 \pm 0.0005$ \\
\hline & & & Subsurface & $0.016 \pm 0.001$ & $0.028 \pm 0.007$ & $0.0018 \pm 0.00005$ & $0.0020 \pm 0.0000007$ \\
\hline & & \multirow[t]{2}{*}{ A } & Surface & $0.230 \pm 0.10$ & $0.356 \pm 0.008$ & $0.0061 \pm 0.001$ & $0.0094 \pm 0.0003$ \\
\hline & & & Subsurface & $0.105 \pm 0.01$ & $0.376 \pm 0.049$ & $0.0059 \pm 0.00069$ & $0.0087 \pm 0.0004$ \\
\hline & & \multirow{2}{*}{$\mathrm{O}$} & Surface & $0.355 \pm 0.029$ & $0.739 \pm 0.03$ & $0.0112 \pm 0.0007$ & $0.0164 \pm 0.0002$ \\
\hline & & & Subsurface & $0.130 \pm 0.0033$ & $0.332 \pm 0.08$ & $0.0197 \pm 0.00093$ & $0.0082 \pm 0.0004$ \\
\hline
\end{tabular}

Data shown are mean values including standard deviations obtained from three replicates.

a Q: Qixia; L: Laishan; P: Penglai.

b Orchards and vineyard type: Young (Y, with age $<10$ years), Adult (A, with age 10-30 years), Old (O, with age $>30$ years).

c Surface: $0-20 \mathrm{~cm}$; subsurface: $20-40 \mathrm{~cm}$.

concentrations on metal availability, the available concentrations are also given as a percentage of the total metal concentration (PTM) in Fig. S1. The $\mathrm{CaCl}_{2}$ extractable $\mathrm{Cu}$ fraction was always $<1.0 \%$, and often $<0.5 \%$, of the total $\mathrm{Cu}$ concentration in soils, while the available $\mathrm{Cd}$ fraction constituted more than $1.0 \%$ of the total $\mathrm{Cd}$ concentration (Fig. S1). Cd availability expressed as PTM increased with orchard and vineyard age. Cd availability was also significantly influenced by soil depth for the adult and old orchards and vineyards and the $\mathrm{CaCl}_{2}$-extractable fraction was generally higher in the subsurface than in the surface soils (ANOVA, $p<0.01$, Fig. S1). The availability of $\mathrm{Zn}$ was also higher in the subsurface than in the surface soils. Only a small proportion ( $<0.1 \%$, and often $<0.05 \%)$ of $\mathrm{Pb}$ was available in the soils (Fig. S1).

No significant correlations between total soil concentrations of $\mathrm{Cd}$ and $\mathrm{Pb}$ and soil properties were found (Table 3). Concentrations of $\mathrm{Cu}$ and $\mathrm{Zn}$ were significantly and negatively correlated with the soil clay and silt content and positively with sand content $(p<0.01)$, while total $\mathrm{Cu}$ concentrations correlated with soil organic carbon content (SOC) $(r=0.58, p<0.01)$ (Table 3). The available metal fractions (PTM) were highly significantly and negatively correlated with soil $\mathrm{pH}\left(R_{\mathrm{adj}}^{2}=0.50-0.61, p<0.001\right.$, Table 3$)$, suggesting that soil acidification had a greater enhancing effect on metal availability than did other soil properties.

The DTPA-extractable concentrations ranged from 0.11 to $4.33 \mathrm{mg} \mathrm{kg}^{-1}$ for $\mathrm{Cu}$, from 0.02 to $0.29 \mathrm{mg} \mathrm{kg}^{-1}$ for $\mathrm{Zn}$, from 0.06 to $1.20 \mathrm{mg} \mathrm{kg}^{-1}$ for $\mathrm{Pb}$, and from 0.0002 to $0.002 \mathrm{mg} \mathrm{kg}^{-1}$ for $\mathrm{Cd}$. DTPA-extractable concentrations decreased with soil depth and were strongly associated with the total soil concentrations $\left(R_{\mathrm{adj}}^{2}=0.39-0.86, p<0.01\right.$, Fig. S2).

\subsection{Soil-water partitioning and DPASV-labile fraction in the extracted soil solution}

The ranges and mean values for metal soil-water partition coefficients $K_{p}$, are listed in Table S1. The results of multiple regression analysis of $\log K_{p}$ with total metal and soil properties (log transformed) are summarized in Equations (1)-(3). For Pb, no variable met the significance level of 0.05 . For $\mathrm{Zn}$, only soil $\mathrm{pH}$ met this level (Equation (1)). Adding other parameters did not significantly improve the regression. As shown in Equations (2) and (3), soil- water partition coefficients of $\mathrm{Cd}$ and $\mathrm{Cu}$ were mainly influenced by soil $\mathrm{pH}$. In addition to soil $\mathrm{pH}$, SOC also influenced the $K_{p}$ of $\mathrm{Cu}$ (Equation (3)).

$\log K_{p Z n}=1.56+0.25 p H R_{\mathrm{adj}}^{2}=0.28, \quad n=18, p<0.01$

$\log K_{p C d}=1.02+0.2 \mathrm{pH}+1.22 \log C d_{\text {total }} R_{\mathrm{adj}}^{2}=0.48, n$

$$
=18, p<0.001
$$

$\log K_{p C u}=2.01-1.08 \operatorname{logSOC}+0.16 \mathrm{pH} R_{\text {adj }}^{2}=0.57, n$

$$
=18, p<0.001
$$

The DPASV-labile $\mathrm{Pb}$ and $\mathrm{Cd}$ concentrations in soil solution increased with orchard and vineyard age, and were also significantly influenced by soil depth (Fig. 3). For the young orchards and vineyard, DPASV-labile $\mathrm{Pb}$ and $\mathrm{Cd}$ was generally higher in the surface soil than subsurface soil, whereas it was opposite in the adult and old orchards and vineyards ( $p<0.05$, Fig. 3 ).

\subsection{Metal speciation in the soil solid phase}

In the orchard and vineyard soils $\mathrm{Zn}$ was mostly found in the residual fraction (70.2-90.7\%), followed by the Fe-Mn oxide (5.2$21.2 \%)$, the exchangeable $(0.3-11.5 \%)$, the carbonate $(3.8-5.5 \%)$ and the organic matter fractions (0.2-1.3\%) (Table S2).

Most of the $\mathrm{Cu}$ in these soils was present in the residual fraction, with exception of the topsoil of older orchard and vineyard soils ( $>10$ years, Table S2). The Fe-Mn oxides bound fraction was the next most important fraction (23.8-58.2\%), whereas the amounts of $\mathrm{Cu}$ in the exchangeable and carbonate-bound fractions were relatively low (Table S2). In particular, the residual fractions of $\mathrm{Cu}$ in the top layers of older orchard and vineyard were much lower than in the deeper layer. 
Table 3

Correlation matrix for relationships between total $(t)$ or available $\left(0.01 \mathrm{M} \mathrm{CaCl}_{2}\right.$ extractable; expressed as percentage of total metal concentration (PTM)) metal concentrations in orchard and vineyard soils from Northeast of Jiaodong Peninsula in China and key soil characteristics (log transformed variables)

\begin{tabular}{lllllll}
\hline Factor & Clay & Silt & Sand & $\mathrm{pH}$ & $\mathrm{SOC}$ & $\mathrm{TM}$ \\
\hline $\mathrm{Cu}_{\mathrm{t}}$ & $-0.57^{* *}$ & $-0.67^{* *}$ & $0.70^{* *}$ & -0.22 & $0.58^{* *}$ & - \\
$\mathrm{Zn}_{\mathrm{t}}$ & $-0.59^{* *}$ & $-0.65^{* *}$ & $0.66^{* *}$ & -0.16 & 0.39 & - \\
$\mathrm{Pb}_{\mathrm{t}}$ & 0.17 & -0.03 & 0.02 & -0.46 & 0.27 & - \\
$\mathrm{Cd}$ & -0.07 & -0.08 & 0.11 & -0.19 & 0.23 & - \\
$\mathrm{PTM}_{\mathrm{Cu}}$ & -0.25 & -0.35 & 0.39 & $-0.74^{* * *}$ & 0.43 & 0.53 \\
$\mathrm{PTM}_{\mathrm{Zn}}$ & -0.09 & -0.16 & 0.14 & $-0.71^{* * *}$ & -0.002 & -0.09 \\
$\mathrm{PTM}_{\mathrm{Pb}}$ & 0.09 & -0.02 & 0.02 & $-0.78^{* * *}$ & 0.13 & 0.31 \\
PTM $_{\mathrm{Cd}}$ & -0.24 & -0.31 & 0.30 & $-0.77^{* * *}$ & 0.41 & 0.05 \\
\hline
\end{tabular}

* Significant at the 0.05 probability level.

** Significant at the 0.01 probability level.

*** Significant at the 0.001 probability level.

SOC represents soil organic carbon content (\%) and TM represents total metal concentration $\left(\mathrm{mg} \mathrm{kg}^{-1}\right)$

No detectable amounts of exchangeable Pb were extracted from the young orchard and vineyard soils, and even in the old orchard soils this fraction contained less than $2.5 \%$ of the total soil $\mathrm{Pb}$ (Table S3). However, the amounts of $\mathrm{Pb}$ extracted by $\mathrm{NH}_{4} \mathrm{OAc}$ were considerably higher (up to $34 \%$ of the total $\mathrm{Pb}$ ), indicating that the $\mathrm{Fe}-\mathrm{Mn}$ oxides bound fraction of $\mathrm{Pb}$ was an important pool in the soils. For Cd, a large amount was detected in the exchangeable fraction (2.1-35.4\%, Table S3).

\subsection{Bioaccumulation of metals by earthworms}

After 28 days of exposure, all earthworms had healthy appearance, and no mortality or significant changes of their mean fresh weight occurred. Internal metal concentrations in E. fetida are presented in Table 4. Mean earthworm tissue concentrations followed the order $\mathrm{Zn}>\mathrm{Cu}>\mathrm{Cd}>\mathrm{Pb}$ (Table 4; ANOVA, $p<0.05$ ). There were significant relationships between earthworm tissue concentrations and the total soil concentrations for $\mathrm{Cu}(p<0.01)$ and $\mathrm{Pb}(p<0.05$; Table 5$)$. The metal concentrations in earthworms showed significant correlations with both the $\mathrm{CaCl}_{2}$ and DTPAextractable soil concentrations except for $\mathrm{Cd}$ and $\mathrm{Zn}$ (Table 5). The internal $\mathrm{Zn}$ concentration was regulated by $E$. fetida to a fairly constant level of approximately $158 \pm 22.4 \mathrm{mg} \mathrm{kg}^{-1}$ dry body weight (Table 4). The unexplained variation in the $\mathrm{Cu}$ and $\mathrm{Pb}$ concentration in earthworms was reduced when related to $\mathrm{CaCl}_{2}$ or DTPA extractable metals concentrations instead of the total metal concentrations in the soil (Table 5).

Bioaccumulation factors (BAFs), determined as the earthworm tissue concentration divided by the soil concentration on a dry weight basis, are summarized in Table 4. The BAFs of the four metals ranked as $\mathrm{Cd}>\mathrm{Zn}>\mathrm{Cu}>\mathrm{Pb}$. The BAFs of $\mathrm{Pb}$ were less than 1 in all cases and for $\mathrm{Cu}$ in most cases with exceptions for vineyard and older orchard soils. The BAFs for all metals decreased with the age of orchards and vineyard in the surface soils, but were higher in the subsurface soils (Table 4).

\section{Discussion}

The average concentrations of $\mathrm{Cu}, \mathrm{Zn}, \mathrm{Pb}$ and $\mathrm{Cd}$ in soils of each age group of orchards were higher than the background values in local agriculture soils (SEPAC, 1990), which may be associated with the more intensive fertilization and protection of apple trees against pests compared to field crops in the studied area, though the pedo-geogenic origin cannot be excluded either. The highest soil contamination of $\mathrm{Cu}$ in apple orchards might be due to the more frequent application of copper-based insecticides and fungicides. Less agri-chemicals are applied in sweet cherry culture as it has the shortest growing period. Concentrations of $\mathrm{Cu}$ found in the vineyard soils in this study were lower than in some renowned wine growing regions such as Europe (Fernandez-Calvino et al., 2008; Flores-Velez et al., 1996), Australia (Pietrzak and McPhail, 2004) and South Africa (up to $3216 \mathrm{mg} \mathrm{kg}^{-1}$ total $\mathrm{Cu}$, Mirlean et al., 2007). In addition, our values were comparable to those found in Australian vineyards (Wightwick et al., 2008). All the $\mathrm{Pb}$ levels in vineyards soils were $<80 \mathrm{mg} \mathrm{kg}^{-1}$, which is the allowable limit for $\mathrm{Pb}$ in farmland soils for edible agricultural crop production in China. Among the adult and old vineyards, the Cd concentrations in the surface soil layer exceeded the maximum allowable concentration of $\mathrm{Cd}\left(0.30 \mathrm{mg} \mathrm{kg}{ }^{-1}\right)$ for agricultural soils in China (SEPAC, 1990). Cd concentrations in some sweet cherry orchards also exceeded the maximum allowable concentration of $\mathrm{Cd}$ $\left(0.30 \mathrm{mg} \mathrm{kg}{ }^{-1}\right)$ for agricultural soils proposed in China (SEPAC, 1990).

$\mathrm{CaCl}_{2}$ extractable $\mathrm{Cu}$ concentrations of vineyard soils reported for several viticultural regions of the world, including the Southern part of France (Brun et al., 1998); Australia (Wightwick et al., 2008); and Brazil (Mirlean et al., 2007), usually represented $<1 \%$, and often $<0.5 \%$, of the total Cu concentration in the soil. This is in agreement with the results of the present study. Even in Brazil, where very high concentrations of accumulated $\mathrm{Cu}$ (1214$3216 \mathrm{mg} \mathrm{kg}^{-1}$ total $\mathrm{Cu}$ ) were found in vineyard soils, $\mathrm{CaCl}_{2}$ extractable $\mathrm{Cu}$ only represented $0.1-0.9 \%$ of the total $\mathrm{Cu}$ concentrations (Mirlean et al., 2007). Considerably higher extractable $\mathrm{Cu}$ concentrations have been reported for acidic vineyard soils (Pietrzak and McPhail, 2004; Brun et al., 1998). Similarly, for the old orchards and vineyard in this study, the acid subsurface soils had relatively higher $\mathrm{CaCl}_{2}$ extractable $\mathrm{Cd}$ concentrations than the surface soils (Table 2), although higher concentrations of $\mathrm{Cd}$ accumulated in the surface layers than in the subsurface.

For the Brown soil (Udic Luvisols) with low metal adsorption capacity, soil acidification may greatly affect the extractability of metals. As shown in Table 3, the availability (represented as the PTM values) of $\mathrm{Cu}, \mathrm{Zn}, \mathrm{Pb}$ and $\mathrm{Cd}$ was mainly influenced by soil solution pH, similar to other reports (Sauvé et al., 2000; Carlon et al., 2004). pH alone could explain $50-61 \%$ of the variability in the available ( $\mathrm{CaCl}_{2}$ extractable) metal fractions (PTM). In addition to soil $\mathrm{pH}$, SOC influences the soil/solution partitioning of $\mathrm{Cu}$, with increasing concentrations of SOC increasing the formation of organic copper complexes.

Most previous investigations on the chemical fractionation of metals in agricultural soils have focused on rice (Xiong et al., 2004), wheat (Nan and Cheng, 2001), and vegetables (Zhou et al., 2000) in China. Very little information is available on the distributions of metals in horticultural soils. Park and Cho (2011) recently reported that $\mathrm{Cu}$ and $\mathrm{Zn}$ were mostly associated with the residual phase in apple orchard soils. It is, however, true that metal in soil could change from one form into another depending on some factors. For instance, if the soil pH declines as a result of acidic amendments or leaching of bases, the metals in the residual form will become more available and mobile in the soil. The sequential extraction of the surface soil samples studied showed that the residual $\mathrm{Cu}$ fraction decreased with increasing orchard age, whereas the Fe or Mn oxide bound fractions increased (Table S2). Sequential chemical extraction data also showed that $\mathrm{Zn}$ in subsurface soil of older orchard and vineyard shifted from dominantly labile, Fe and Mn oxides sorbed forms ( $\mathrm{NH}_{4} \mathrm{AC}$ extractable) towards more mobile fractions i.e., to the exchangeable fraction, as a result of strong subsoil acidification. Acidification of the subsurface soil mainly attributed to the release of $\mathrm{Zn}$ bound to Fe and Mn oxides and of the carbonate bound $\mathrm{Zn}$ fraction. This resulted in a large increase of the Fe and $\mathrm{Mn}$ extractable fraction (data not shown). A large amount of Cd was 
(a)

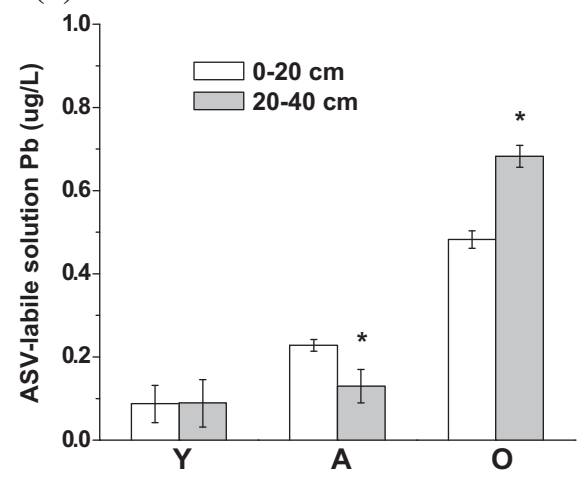

(b)

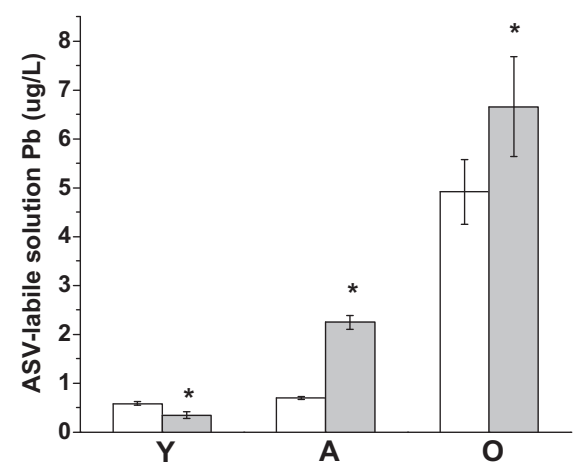

(c)

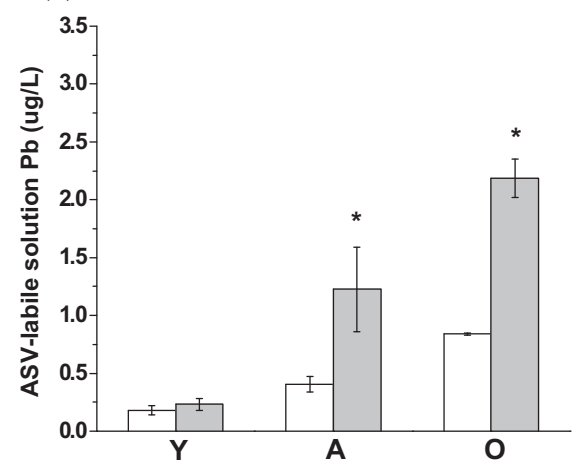

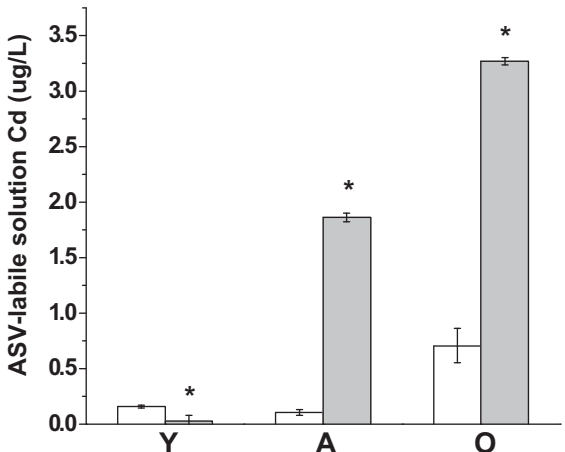
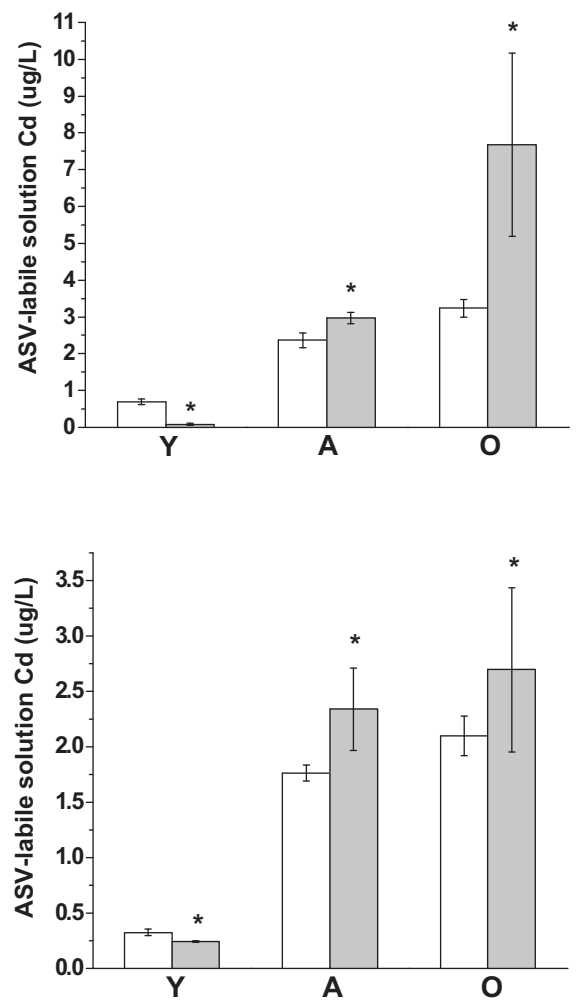

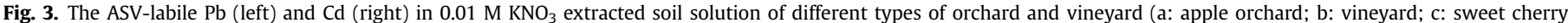

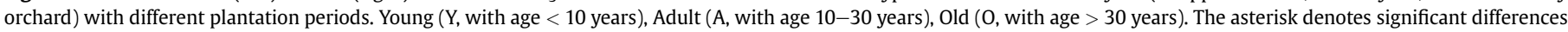
between surface $(0-20 \mathrm{~cm})$ and subsurface $(20-40 \mathrm{~cm})$ horizon for a specific orchard or vineyard age at $p<0.05$.

detected in the exchangeable fraction and the residual fractions of $\mathrm{Cd}$ in the subsurface layers of old orchard and vineyard soils sharply decreased, as compared to the top layer (Table S3). This too could be largely attributed to the higher acidity in the subsoil. Finally, acidification did not significantly influence the solid phase speciation of $\mathrm{Cu}$ and $\mathrm{Pb}$ as they were only to a small extent bound to carbonates and Fe or Mn oxides in the examined soils.

The concentrations of $\mathrm{Cu}$ and $\mathrm{Pb}$ accumulated by E. fetida in this experiment are comparable to those reported by other studies using soils containing similar concentrations of aged metals (Gaw et al., 2012). The significant relationships observed between earthworm and soil concentrations of $\mathrm{Cu}(p<0.001)$ and $\mathrm{Pb}$ $(p<0.01$; Table 5) were consistent with correlations previously reported for E. fetida in laboratory exposure assays with metalcontaminated field soils (Grelle and Descamps, 1998; Bleeker and van Gestel, 2007). The Cu concentration in earthworms exposed to the seven soils containing the highest $\mathrm{Cu}$ concentrations exceeded $40 \mathrm{mg} \mathrm{kg}^{-1}$, the critical body concentration for cocoon production for A. caliginosa and L. rubellus (Ma, 2005).

The order of uptake of metals and the magnitude of the BAFs (Table 4) were in agreement with the results recently reported for earthworms exposed to orchards soils contaminated by metals as a result of historical agrichemical applications (Gaw et al., 2012). The BAFs demonstrated marked differences in accumulation of metals in subsurface soil of the aged orchards and vineyard, as evidenced by the highest BAFs, with BAFs exceeding 1 for $\mathrm{Cu}, \mathrm{Zn}$ and $\mathrm{Cd}$ (Table 4). A BAF value of one or greater indicates that the earthworms accumulated the metals from the orchard and vineyard soils. Since $\mathrm{Zn}$ and $\mathrm{Cu}$ are essential elements, the high BAF may to a great extent be explained from the regulation of body concentrations by the earthworms rather than from too high exposure levels. These results nevertheless suggest that transfer to the food chain of 
Table 4

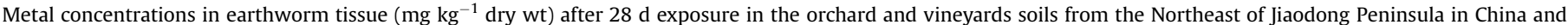
bioaccumulation factors (BAFs) for uptake of metals by the earthworm Eisenia fetida. See Table S1 for soil properties and Fig. 2 for metal concentrations.

\begin{tabular}{|c|c|c|c|c|c|c|c|c|c|c|c|}
\hline \multirow[t]{2}{*}{ Site $^{\mathrm{a}}$} & \multirow[t]{2}{*}{ Type } & \multirow[t]{2}{*}{ Age (years) } & \multirow[t]{2}{*}{ Layer $^{\mathrm{b}}$} & \multicolumn{4}{|c|}{ Worm metal concentration ( $\mathrm{mg} \mathrm{kg}^{-1}$ dry wt) } & \multicolumn{4}{|c|}{ Metal bioaccumulation factors (BAFs) ${ }^{c}$} \\
\hline & & & & $\mathrm{Cu}$ & $\mathrm{Zn}$ & $\mathrm{Pb}$ & $\mathrm{Cd}$ & $\mathrm{Cu}$ & $\mathrm{Zn}$ & $\mathrm{Pb}$ & $\mathrm{Cd}$ \\
\hline \multirow[t]{6}{*}{$\mathrm{Q}$} & \multirow[t]{6}{*}{ Apple orchard } & \multirow[t]{2}{*}{$<10$} & Surface & 21.1 & 149 & 3.4 & 37.4 & 0.31 & 1.17 & 0.10 & 139 \\
\hline & & & Subsurface & 33.2 & 130 & 2.7 & 29.2 & 0.73 & 1.22 & 0.11 & 154 \\
\hline & & \multirow[t]{2}{*}{10 to 30} & Surface & 46.7 & 150 & 3.1 & 40.1 & 0.73 & 1.08 & 0.08 & 103 \\
\hline & & & Subsurface & 28.1 & 148 & 2.7 & 24.3 & 0.73 & 1.32 & 0.09 & 93.8 \\
\hline & & \multirow[t]{2}{*}{$>30$} & Surface & 58.5 & 141 & 2.7 & 36.0 & 0.44 & 0.83 & 0.05 & 88.0 \\
\hline & & & Subsurface & 51.8 & 170 & 4.0 & 38.9 & 1.15 & 1.43 & 0.12 & 216 \\
\hline \multirow[t]{6}{*}{$\mathrm{P}$} & \multirow[t]{6}{*}{ Vineyard } & \multirow[t]{2}{*}{$<10$} & Surface & 42.5 & 174 & 3.4 & 46.2 & 1.49 & 2.32 & 0.11 & 185 \\
\hline & & & Subsurface & 29.3 & 151 & 2.5 & 35.6 & 1.11 & 2.15 & 0.11 & 149 \\
\hline & & \multirow[t]{2}{*}{10 to 30} & Surface & 35.5 & 142 & 4.2 & 21.1 & 0.69 & 1.49 & 0.05 & 43.1 \\
\hline & & & Subsurface & 31.4 & 151 & 3.8 & 34.1 & 1.21 & 1.82 & 0.08 & 97.5 \\
\hline & & \multirow[t]{2}{*}{$>30$} & Surface & 70.8 & 161 & 4.1 & 30.8 & 0.88 & 2.15 & 0.05 & 54.1 \\
\hline & & & Subsurface & 26.9 & 132 & 3.3 & 27.2 & 1.05 & 2.03 & 0.06 & 114 \\
\hline \multirow[t]{6}{*}{$\mathrm{L}$} & \multirow[t]{6}{*}{ Sweet cherry orchard } & \multirow[t]{2}{*}{$<10$} & Surface & 34.5 & 135 & 2.5 & 30.8 & 1.03 & 1.50 & 0.09 & 110 \\
\hline & & & Subsurface & 34.4 & 159 & 2.9 & 27.8 & 1.07 & 2.01 & 0.10 & 155 \\
\hline & & \multirow[t]{2}{*}{10 to 30} & Surface & 33.8 & 167 & 2.3 & 32.7 & 0.74 & 1.64 & 0.08 & 109 \\
\hline & & & Subsurface & 38.4 & 177 & 3.7 & 34.5 & 1.05 & 2.06 & 0.14 & 216 \\
\hline & & \multirow[t]{2}{*}{$>30$} & Surface & 42.7 & 196 & 3.3 & 39.3 & 0.44 & 1.27 & 0.06 & 87.4 \\
\hline & & & Subsurface & 45.6 & 216 & 4.9 & 40.8 & 1.35 & 3.25 & 0.20 & 227 \\
\hline
\end{tabular}

a Q: Qixia L: Laishan P: Penglai.

b Surface: $0-20 \mathrm{~cm}$ subsurface: $20-40 \mathrm{~cm}$.

${ }^{c}$ BAFs calculated as earthworm tissue concentration ( $\mathrm{mg} \mathrm{kg}^{-1}$ ) divided by soil concentration ( $\mathrm{mg} \mathrm{kg}^{-1}$ ) on dry weight basis; unit of BAF is $\mathrm{kg}^{-}$earthworm $\mathrm{kg}^{-1}$ soil.

Table 5

Correlation matrix for metal concentrations in earthworm tissue and extracted soil concentrations (log-transformed variables). The earthworm Eisenia fetida were exposed for $28 \mathrm{~d}$ in the orchard and vineyard soils from the Northeast of Jiaodong Peninsula in China.

\begin{tabular}{lcccc}
\hline & $\begin{array}{l}\text { Soil total } \\
\text { concentration }\end{array}$ & $\begin{array}{l}\mathrm{CaCl}_{2} \\
\text { extractable }\end{array}$ & $\begin{array}{l}\mathrm{DTPA} \\
\text { extractable }\end{array}$ & $\begin{array}{l}\text { Soil solution } \\
\text { concentration }\end{array}$ \\
\hline $\mathrm{Cu}_{\text {worm }}$ & $0.55^{* *}$ & $0.70^{* * *}$ & $0.63^{* *}$ & 0.33 \\
$\mathrm{Zn}_{\text {worm }}$ & -0.07 & 0.20 & -0.23 & 0.26 \\
$\mathrm{~Pb}_{\text {worm }}$ & $0.40^{*}$ & $0.58^{* *}$ & $0.50^{*}$ & 0.16 \\
$\mathrm{Cd}_{\text {worm }}$ & -0.15 & -0.26 & 0.08 & -0.38 \\
\hline
\end{tabular}

*Significant at the 0.05 probability level.

**Significant at the 0.01 probability level.

*** Significant at the 0.001 probability level.

Cd is possible in old orchards and vineyards with elevated concentrations and bioavailability of these metals in the subsurface soil layer.

The results reported in the present study confirmed the enrichment of soil with $\mathrm{Cu}, \mathrm{Zn}, \mathrm{Pb}$ and $\mathrm{Cd}$ due to the use and management of orchards and vineyards with agri-chemicals for various decades in a certified fruit plantation area of the Northeast Jiaodong Peninsula, China. Our results also demonstrated that these historical horticultural metals remained bioavailable to the earthworm E. fetida, specifically in the old orchards and vineyards, largely due to soil acidification and that the potential exists for $\mathrm{Cd}$ to enter terrestrial food chains. Regular monitoring (i.e., every two years) of the soil conditions at the old orchards and vineyards is therefore recommended in order to assess the solubility of $\mathrm{Cu}, \mathrm{Zn}$, $\mathrm{Pb}$ and $\mathrm{Cd}$ and limit their entrance into the food chain, and to allow for taking possible measures to oppose soil acidification. Specifically, orchard soil metal guidelines (National Environmental Protection Agency of China (1995)) may need to be re-evaluated to afford appropriate environmental protection under conditions of acidification.

\section{Acknowledgments}

This study is supported by the National Natural Science Foundation (No. Y 311111031) and The 100 Talents Program of the Chinese Academy of Sciences. The authors are grateful for the assistance in soil samples collection from Dr. Shiwei Zhou. We also want to thank Prof. Yongming Luo from Yantai Institute of Coastal Zone Research (YIC), Chinese Academy of Sciences (CAS) for his constructive comments in the improvement of the manuscript.

\section{Appendix A. Supplementary data}

Supplementary data related to this article can be found at http:// dx.doi.org/10.1016/j.envpol.2014.02.003.

\section{References}

Allen, H.E., 2002. Terrestrial ecosystems: an overview. In: Allen, H.E. (Ed.), Bioavailability of Metals in Terrestrial Ecosystems: Importance of Partitioning for Bioavailability to Invertebrates, Microbes and Plants. SETAC Press, Pensacola, FL, pp. $1-5$.

Amacher, M.C., 1996. Nickel, cadmium, and lead. SSSA Book Series No 5. In: Sparks, D.L. (Ed.), Methods of Soil Analysis, Part 3: Chemical Methods. ASA-CSASSSA Inc., Madison, WI, pp. 739-768.

Bleeker, E.A.J., van Gestel, C.A.M., 2007. Effects of spatial and temporal variation in metal availability on earthworms in floodplain soils of the river Dommel, The Netherlands. Environ. Pollut. 148, 824-832.

Brun, L.A., Maillet, J., Richarte, J., Herrmann, P., Remy, J.C., 1998. Relationships between extractable copper, soil properties and copper uptake by wild plants in vineyard soils. Environ. Pollut. 102, 151-161.

Carlon, C., Valle, M.D., Marcomini, A., 2004. Regression models to predict water-soil heavy metals partition coefficients in risk assessment studies. Environ. Pollut. 127, 109-115.

Chopin, E.I.B., Marin, B., Mkoungafoko, R., Rigaux, A., Hopgood, M.J., Delannoy, E., Cancès, B., Laurain, M., 2008. Factors affecting distribution and mobility of trace elements $(\mathrm{Cu}, \mathrm{Pb}, \mathrm{Zn})$ in a perennial grapevine (Vitis vinifera $\mathrm{L}$.) in the Champagne region of France. Environ. Pollut. 156, 1092-1098.

Conder, J., Lanno, R., 2003. Lethal critical body residues as measures of Cd, Pb, and Zn bioavailability and toxicity in the earthworm Eisenia fetida. J. Soils Sediment $3,13-20$.

Delusia, A., Giandon, P., Aichner, M., Bortolami, P., Bruna, L., Lupetti, A., Nardelli, F., Stringari, G., 1996. Copper pollution in Italian vineyard soils. Commun. Soil Sci. Plant Anal. 27, 1537-1548.

Fan, J.H., He, Z.L., Ma, L., Stoffella, P.J., 2011. Accumulation and availability of copper in citrus grove soils as affected by fungicide application. J. Soils Sediments 11, 639-648.

Fernandez-Calvino, D., Pateiro-Moure, M., Lopez-Periago, E., Arias-Estevez, M., Novoa-Munoz, J.C., 2008. Copper distribution and acid-base mobilization in vineyard soils and sediments from Galicia (NW Spain). Eur. J. Soil Sci. 59, 315326.

Flores-Velez, L.M., Ducarior, J., Jaunet, A.M., Robert, M., 1996. Study of the distribution of copper in an acid sandy vineyard soil by three different methods. Eur. J. Soil Sci. 47, 523-532. 
Gaw, S., Northcott, G., Kim, N., Wilkins, A., Jensen, J., 2012. Comparison of earthworm and chemical assays of the bioavailability of aged 1,1-dichloro-2,2-bis ( $p$ chlorophenyl) ethylene,1,1,1-trichloro-2,2-bis ( $p$-chlorophenyl) ethane, and heavy metals in orchard soils. Environ. Toxicol. Chem. 31, 1306-1316.

Grelle, C., Descamps, M., 1998. Heavy metal accumulation by Eisenia fetida and its effects on glutathione-S-transferase activity. Pedobiologia 42, 289-297.

Guo, H., Zhu, J., Zhou, H., Sun, Y., Yin, Y., Pei, D., Ji, R., Wu, J., Wang, X.R., 2011. Elevated $\mathrm{CO}_{2}$ levels affects the concentrations of copper and cadmium in crops grown in soil contaminated with heavy metals under fully open-air field conditions. Environ. Sci. Technol. 2011 (45), 6997-7003.

Guo, J.H., Liu, X.J., Zhang, Y., Shen, J.L., Han, W.X., Zhang, W.F., Christie, P., Goulding, K.W.T., Vitousek, P.M., Zhang, F.S., 2010. Significant acidification in major Chinese croplands. Science 327, 1008-1010.

Hood, E., 2006. The apple bites back: claiming old orchards for residential development. Environ. Health Perspect. 114, A470-A476.

Li, L.Z., Zhou, D.M., Wang, P., Allen, H.E., Sauve, S., 2009. Predicting Cd partitioning in spiked soils and bioaccumulation in the earthworm Eisenia fetida. Appl. Soil. Ecol. 42, 118-123.

Lock, K., Janssen, C.R., 2001. Zinc and cadmium body burdens in terrestrial oligochaetes: use and significance in environmental risk assessment. Environ. Toxicol. Chem. 20, 2067-2072.

Ma, W., 2005. Critical body residues (CBRs) for ecotoxicological soil quality assessment: copper in earthworms. Soil Biol. Biochem. 37, 561-568.

Martinez-Villegas, N., Martinez, C.E., 2008. Solid- and solution-phase organics dictate copper distribution and speciation in multi-component systems containing ferrihydrite, organic matter, and montmorillonite. Environ. Sci. Technol. 42, 2833-2838.

Merrington, G., Rogers, S.L., Van Zwieten, L., 2002. The potential impact of longterm copper fungicide usage on soil microbial biomass and microbial activity in an avocado orchard. Aust. J. Soil. Res. 40, 749-759.

Mirlean, N., Roisenberg, A., Chies, J.O., 2007. Metal contamination of vineyard soils in wet subtropics (southern Brazil). Environ. Pollut. 149, 10-17.

Nan, Z.R., Cheng, G., 2001. Accumulation of Cd and Pb in spring wheat (Triticum aestivum L.) grown in calcareous soil irrigated with wastewater. Bull. Environ. Contam. Toxicol. 66, 748-754.

National Environmental Protection Agency of China, 1995. Environmental Quality Standard for Soils (GB 15618-1995).

Organization for Economic Cooperation and Development, 2004. Guideline for Testing of Chemicals 222. In: Earthworm Reproduction Test (Eisenia fetida/ Eisenia andrei) (Paris, France).

Park, B.J., Cho, J.Y., 2011. Assessment of copper and zinc in soils and fruit with the age of an apple orchard. J. Korean Soc. Appl. Bi 54, 910-914.

Peijnenburg, W.J.G.M., Baerselman, R., de Groot, A.C., Jager, T., Posthuma, L., Van Veen, R.P.M., 1999. Relating environmental availability to bioavailability: soil- type-dependent metal accumulation in oligochaete Eisenia andrei. Ecotoxicol Environ. Saf. 44, 294-310.

Peijnenburg, W.J.G.M., Zablotskaja, M., Vijver, M.G., 2007. Monitoring metals in terrestrial environments within a bioavailability framework and a focus on soil extraction. Ecotoxicol. Environ. Saf. 67, 163-179.

Pendergrass, A., Butcher, D.J., 2006. Uptake of lead and arsenic in food plants grown in contaminated soil from Barber Orchard, NC. Microchem. J. 83, 14-16.

Pietrzak, U., McPhail, D.C., 2004. Copper accumulation, distribution and fractionation in vineyard soils of Victoria, Australia. Geoderma 122, 151-166.

Sauvé, S., Norvell, W.A., McBride, M.B., Hendershot, W.H., 2000. Speciation and complexation of cadmium in extracted soil solutions. Environ. Sci. Technol. 34 291-296.

SEPAC (State Environmental Protection Administration of China), CEMCS (China Environmental Monitoring Central Station), 1990. The Background Values of Soil Elements in China. China Environmental Science Press, Beijing, p. 130 (in Chinese).

Spurgeon, D.J., Hopkin, S.P., 1999. Comparisons of metal accumulation and excretion kinetics in earthworms (Eisenia fetida) exposed to contaminated field and laboratory soils. Appl. Soil. Ecol. 11, 227-243.

Stephan, C.H., Courchesne, F. Hendershot, W.H., McGrath, S.P., Chaudri, A.M., Sappin-Didier, V., Sauvé, S., 2008. Speciation of zinc in contaminated soils. Environ. Pollut. 155, 208-216.

Tang, C., Raphael, Z., Rengel, C., Bowden, J.W., 2000. Understanding subsoil acidification: effect of nitrogen transformation and nitrate leaching. Aust. J. Soil. Res. 38, 837-849.

Udovic, M., McBride, M.B., 2012. Influence of compost addition of lead and arsenic bioavailability in reclaimed orchard soil assessed using Porcellio scaber bioaccumulation test. J. Hazard. Mater. 205, 144-149.

van Gestel, C.A.M., 2012. Soil ecotoxicology: state of the art and future directions Zookeys 176, 275-296.

Vijver, M.G., van Gestel, C.A.M., van Straalen, N.M., Lanno, R.P. Peijnenburg, W.J.G.M., 2006. Biological significance of metals partitioned to subcellular fractions within earthworms (Aporrectodea caliginosa). Environ. Toxicol. Chem. 25, 807-814.

Wightwick, A., Mollah, M., Partington, D., Allinson, G., 2008. Copper fungicide residues in Australian vineyard soils. J. Agric. Food Chem. 56, 2457-2464.

Xiong, X., Allinson, G., Stagnitti, F., Li, P., Wang, X., Liu, W., Allinson, M., Turoczy, N. Peterson, J., 2004. Cadmium contamination of soils of the Shenyang ZhanShi irrigation area, China: an historical perspective. Bull. Environ. Contam. Toxicol. 73, 270-275.

Zhou, Z.Y., Fan, Y.P., Wang, M.J., 2000. Heavy metal contamination in vegetables and their control in China. Food Rev. Int. 16, 239-255. 